\title{
The 'Parties' Presidents Make? \\ The Bush Legacy and Party Government
}

\author{
Joseph Mink
}

Although elected without having won the popular vote, George W. Bush set out to enact an ambitious legislative agenda designed, in part, to help secure a "permanent majority” for the GOP. In pursuing this agenda, Bush drew upon significant institutional advantages associated with the contemporary state of political parties, and he worked diligently to reinforce those advantages by dedicating himself to a party building effort unprecedented in modern politics. In this article I explore how these efforts may put into question the framework of realignment and propose instead a trajectory of presidential led parties.

"It was closely split in 2000. I am not certain it is so closely split now. ... Something is going on out there. I attribute it to the president, to the president's agenda, to quality candidates and quality campaigns, to some tactical advantages in our ground game, our getting out the vote, but I think something more fundamental is happening there, but we will only know it retrospectively, in two years or four years or six years [when we] look back and say the dam began to break in 2002” (Rove 2003, para. 37).

-Karl Rove, "What Makes a Great President?”

\section{Introduction}

In November, 2002 Karl Rove delivered an address at the University of Utah entitled "What Makes a Great President." For the most part, Rove's analysis was quite ordinary, and he repeated the sort of common sense standards for presidential evaluation that are often expressed by presidential historians and political pundits: successful presidents require a "clarity of vision," the flexibility to adjust to circumstances especially during crises, the ability to deal with legacies left to them by previous presidents, "emotional intelligence" (as put forth by Fred Greenstein), a "healthy respect for public opinion" but also the "leadership to change public opinion," and finally, a staff that is able and willing to provide candor and thoughtful advice even when, especially when, that meant challenging the president's interpretation of both governing principles and events (Rove 2002). Despite the conventional wisdom expressed, the speech (and the question and answer session that followed) has drawn attention from commentators attempting to

JOSEPH MINK is an assistant professor of political science at the New College of Florida.

The American Review of Politics, Vol. 29, Winter, 2008-2009: 311-329

(C)2008 The American Review of Politics 
understand Rove and the president he served. In particular, Rove's admiration for William McKinley and his previous comparisons of the 2000 elections with those that took place in 1896 have served as a framework for interpreting his stated goal of establishing a "permanent Republican majority" (Green 2007, para. 27-32).

The address was not the first time Rove expressed his belief that McKinley was underappreciated as a president. Although "history demanded little of him," the lack of defining crises during McKinley's administration should not obscure his considerable talents and successes. McKinley, Rove argued, should be recognized for his impact in transforming the Treasury into an institution capable of dealing with "the modern economy," and more importantly, McKinley should be recognized as the principle "architect" (a moniker Bush would bestow on Rove after his successful reelection in 2004) responsible for the transformation of the Republican Party during the 1890s that established "a durable governing coalition for 40 years." During Bush's first presidential campaign Rove drew upon the realignment of 1896 as a means of explaining what he thought was occurring in contemporary politics; McKinley occupied a rare position in American history because he understood that the nation was undergoing an important transformation, and of equal importance, Rove believed that the United States was in a similar situation in 2000 (Rove 2002, para. 23-24, 59-66, quotes 24; Green 2007, para. 27-32; Lemann 2003, para. 22 and 35).

Of particular concern for Green (2007) is that Rove attempted to bring about this realignment of U.S. politics without what Paul Allen Beck has labeled a "societal trauma" (Beck 1997). Given the peace and prosperity of the late 1990s, any potential for realignment lacked "an obvious trigger" and so Rove proposed to "use the levers of government to create" the necessary conditions "through a series of far-reaching policies." One issue that defined Bush's initial run for the presidency was his promise to deliver substantial tax cuts, a promise that had broad appeal among the different components of the GOP coalition and a promise the president would keep (Tax Relief Reconciliation Act of 2001). But in addition, Bush proposed an ambitious agenda that included education reform, a restructuring of Medicare, the partial privatization of Social Security, government sponsorship of faith based initiatives, and new immigration laws. Rove believed that these policies could be formulated to mobilize and ensure the political loyalty of conservatives while simultaneously appealing to select Democratic and Independent voters (conservative and religious Blacks, women concerned about education, Catholics who voted on cultural issues, Hispanics, and the elderly) (Green 2007, para. 9-13; Lemann 2003, para. 42-43).

By the time of Rove's address in 2002, he believed that he might have witnessed the beginning of that realignment. The parity between the GOP 
and the Democratic Party that had defined elections in the 1990s seemed to have been disrupted; Republican candidates received between 52 and 53 percent of total votes cast compared to only 47 percent for the Democrats, and the GOP picked up seats in both houses of Congress. While Bush (and Rove) would be widely credited for engineering that victory, six years later a Republican majority that would outlast the president's tenure in office was unrealized. In 2004 Bush had been reelected with a majority of the popular vote, and some evidence suggested that more Americans identified themselves as Republicans than Democrats (Campbell 2008, 29-30). However, in 2006, Democrats recaptured both houses of Congress. Political commentators (and the president) interpreted the election as a rejection of Bush's leadership in general, and the Iraq war in particular. And the victory of Barack Obama (which included the new president winning 52 percent of the vote and carrying nine states that Bush had won in 2004) coupled with the Democratic Party consolidating their majorities in the Senate and the House has lead to speculation that realignment has occurred (just not the one Bush and Rove envisioned). Or put another way, it would seem as though Bush's and Rove's attempt to secure their respective legacies through securing a permanent Republican majority may well have resulted in a legacy of failure and a majority that is Democratic (Wilentz 2006, 2008; Davis 2008; Judis 2008; Meyerson 2008).

This essay will not attempt to explain the sudden and dramatic downfall of George W. Bush or the Republican Party. Instead, my interests are twofold. First, Rove's plan to trigger a realignment of the American political system implied an ambiguous place for Bush in terms of the Reagan Revolution, to which he claimed loyalty, and from which he drew much of his authority. When Bush took office in 2000 the Republicans for the first time since the 1920s controlled both houses of Congress and the Presidency. Although Reagan's win in 1980 is often considered a fundamental turning point in American politics, neither Reagan nor George H.W. Bush had governed with the Republicans in control of Congress. These twelve years of divided government were followed by eight years of Clinton occupying the White House (six of which also resulted in divided government as the Republicans finally captured Congress in 1994). Divided government was no longer an aberration, it had become the norm. Although it was clear that the structure of politics in the United States had been altered by the disruption of the FDR coalition that began in the 1960s and continued through Reagan's dramatic victories in 1980s, there has been considerable debate among scholars about the significance and extent of what those victories have meant in terms of American politics (Beck 1997, 165-167, 131-136, 384-388; Sundquist 1988; Ladd 1990). 
In 2000, Rove believed that the political climate reflected the electorate's exhaustion with both parties. But with Republicans still in control of Congress in 2000, Bush's victory promised the possibility of finally reconstructing the American polity in terms of conservative commitments. What was unclear was whether Bush's vision of "compassionate conservatism" was simply an extension of the Reagan Revolution designed to complete the "rolling" realignment that began in the 1960s or if the president was attempting a new realignment that would reinvigorate the GOP in the same way that McKinley was able to reconstruct his party in 1896. In either case, Rove's "permanent Republican majority" would address the one glaring 'deficiency' of the Reagan Revolution, the Republicans' inability to consolidate their 'philosophical' victory into an unquestioned political one.

Second, Bush quickly came to understand that employing "compassionate conservatism" to establish a durable Republican majority could not be guaranteed solely through the innovative programmatic commitments he had offered during his campaign. So while the president was able to achieve some immediate legislative successes relying upon Republican support in Congress for his proposed tax cuts and working with both Republicans and Democrats on No Child Left Behind, he also began working to secure and expand Republican majorities in both houses of Congress. Bush's willingness to devote his time, energy, and reputation in the recruitment of candidates, fundraising efforts, and actively campaigning on behalf of Republicans had helped the party win in 2002. This dedication to party building is unusual in the contemporary era of candidate-centered elections and expansive administrative powers that make the president less dependent upon party support (King 1997; Skowronek 1997; Milkis 1999). In pursuing a durable Republican majority through party building, I want to suggest that Bush may have been practicing a politics indicative of a new kind of presidency and a politics made possible by a new kind of party.

\section{Bush's Place in Political Time}

"Neustadt's periodization of presidential history-his distinction between modern and premodern contexts for the exercise of power-introduced a sense of coherence into the relentless succession of incumbents and raised the study of leadership efforts above the idiosyncrasies of the case at hand. But simple periodization schemes impose severe limits on the analysis of leadership" (Skowronek 1997, 5).

—Stephen Skowronek, The Politics Presidents Make

Rove's fascination with presidential legacy and political realignment raises intriguing questions about how historians and political scientists 
evaluate presidential performance. But Rove's belief that President Bush could reconstruct the political order in a manner that would ensure a durable Republican majority also raises important questions about the extent to which presidents are able to control their own fate. For Stephen Skowronek, the tension between an individual president's desire to make his individual stamp on the office and the requirement that the president has a foundation upon which he can exercise authoritative leadership both imposes limits on presidential leadership and alters the enduring structural components of the American political system.

In The Politics Presidents Make, Skowronek challenges the perceived standards for evaluating presidential performance, encouraging presidential scholars to reconsider both the significance of skill and character (Neustadt 1960) in judging the relative success or failure of particular presidents and the demarcation of modernity that was thought to make those skills and that character absolutely essential (Skowronek 1997, 3-15). Although every president hopes to secure his own legacy, presidents do not all begin with the same opportunity to measure their accomplishments against others based only upon their skills and character. As a remedy for this preoccupation with political skill or character and the accepted periodization of political development that separated 'modern' presidents from those in the past, Skowronek identified three patterns of political development into which presidents can be situated and compared across time: a "persistent pattern of political disruption" that occurs as each new president exercises his powers dislodging the previous administration; an "emergent pattern of expanding resources and greater independence in presidential action," or "secular time" that results from the development and transformation of how political power is organized and practiced (Patrician, Partisan, Pluralist, and Plebiscitary); and a "recurrent pattern of founding, fragmenting, and disintegration" of the "basic commitments of ideology and interest" that have defined "governing coalitions and party systems," or "political time" (Skowronek 1997, 3-10, 17-19, 34-45, and 49-58).

While the first pattern reflects an unchanging, and the second an evolving, source of presidential power (and have been the starting point for most presidential scholarship), it is the third pattern of recurrent cycles of "political time" that reflects different claims to presidential authority depending upon the president's relationship to the dominant political regime and the relative strength of that regime. Presidents can be sorted into four categories by the politics they practice (reconstruction, articulation, preemption, or disjunction). Realignment theory can help us to understand how a president's relation to the dominant coalitions can limit or enhance presidential authority in "political time" both in terms of its periodization of politics across time and the patterns of contestation, decline, and reconstruction it 
identifies. Skowronek's specific formulation of a complex historical framework provides three important advantages to the study of the presidency: first, it allows scholars to compare presidents to those similarly situated in either "political" or "secular time;" second, it identifies both the disruptive role that presidents play in "political time" and the role they may play in "secular" development, capturing how the choices made by individual presidents inform development within and across different regimes; finally, it reveals how the development that takes place in "secular time" may profoundly impact the recurrent patterns of presidential authority as they play out in "political time."

Employing Skowronek's typology to classify the presidency of George W. Bush reveals three accounts of his leadership. One common thread running through these interpretations of the Bush presidency is the unusual, and perhaps unique, relationship that existed between the president and his party. First, Sidney Milkis draws out important similarities between Bush's campaign in 2000 and the "third way" politics of preemption practiced by Bill Clinton. As Bush articulated his vision of "compassionate conservatism" during the campaign, Milkis claims that he often recalled the basic values of "responsibility," "community," and "education" that served as the foundation for the Clinton's new covenant. In particular, Bush recognized a positive role for government (even in securing some of the most basic conservative policies and principles). His belief that "government should be active, but limited, engaged but not overbearing" seemed strangely at odds Reagan's claim in his First Inaugural that "government is not the solution to our problem, government is the problem" (Milkis and Nelson 2003, 411414, Bush quote 413).

And while Bush worked closely with Republicans in order to secure the passage of his tax relief package, the president also initially demonstrated a willingness to work with liberal Democrats in pursuing policies constructing temporary bipartisan coalitions. Education reform may have been the policy issue most identified with Bush's “compassionate conservatism.” In Texas, Bush had demonstrated his command of the issue and his passionate commitment to reform, but in passing legislation at the national level, he displayed a "third way" pragmatism working more closely with Senator Edward Kennedy and his staff than with the Education Committee chairman, Republican Jim Jeffords. The result was a bill that balanced increased spending on education with a requirement for developing and meeting explicit standards, however, the inclusion of those standards hardly placated conservatives who had long believed that any serious attempt at education reform should include vouchers (Milkis and Nelson 2003, 411-414, quotes from 412; Sinclair 2008, 172-174). 
The similarities between Bush and Clinton end, however, when comparing their commitments to party. While Clinton failed to explain the relationship between his leadership and "the core principles of the Democratic party" and showed little concern for party building, Milkis believes that Bush was careful to explain how his vision of government drew upon the conservative tradition of the Republican Party. Governing with a bare majority in the House and a Senate controlled by the opposition after Jeffords's decision to caucus with the Democrats, the president took the lead in readying his party for 2002 midterm elections, instructing Rove to both devise an electoral strategy and to recruit candidates capable of successfully executing that strategy, trumping any concerns about either conservative orthodoxy or interfering with state party organizations. But because Rove was also involved in the formation of domestic policy, political considerations and electoral strategies became part of the same set of calculations. Finally, Bush did his part, raising \$141 million for GOP candidates and taking part in a grueling campaign schedule (Milkis and Nelson 2003, 411414 and 419-420, quote 413; Milkis 1999, 157-173).

If Milkis's interpretation of Bush as a "third way" president is correct, then this may mark the beginning of the perpetual state of preemption that Skowronek suggests is one possible path to the future. He believed that while secular development constrained the politics of reconstruction and articulation, it also offered presidents "more freedom than ever to resist traditional roles," encouraging the politics of preemption. This sort of development was exemplified in Reagan's reconstruction of political order; although he successfully changed political discourse, including providing a new set of arguments could be employed to legitimate political decisions, the "institutional commitments of the liberal regime" remained. So while a Republican, and a conservative one, Bush may have found it more advantageous to at least partially free himself from the Reagan legacy and chart his own path in a political universe in which "Republicans and Democrats alike . . . find themselves hard pressed to come up with a credible case for governing” (Skowronek 1997, 442-446 and 428-429).

Despite his earlier predictions that "political time" may be coming to a close, however, Skowronek develops a second interpretation, classifying Bush as an "orthodox-innovator." Bush distanced himself from both the failed leadership of his father and the "third way" politics of Bill Clinton, adopting an unshakeable belief in his own orthodoxy and an almost intractable dedication to his decisions. Skowronek argues that the president attempted to dispel any perception that either he lacked a firm commitment to conservative values like his father or that he would continue the "moral confusion, feckless character, and official disgrace" suffered by Clinton. This political stance constructed upon "leadership by definition" signaled to 
voters what kind of "leader this man intends to be: the kind who lays out terms and upholds them against all comers" (Skowronek 2008, 117-149, quotes from 131 and 122).

Claiming authority as a faithful son of the Reagan Revolution, Bush's articulation of "compassionate conservatism" should not be seen, according to Skowronek, as a means of engaging in "third way" politics, but rather should be interpreted as an attempt to build upon the commitments of Reagan, promising that the underlying tenets would remain and suggesting "the possibility of a higher ordering of those same values." Even Bush's willingness to compromise on issues like education reform was not the result of some political pragmatism, but instead reflected deeply held beliefs and a pledged commitment to bipartisanship (Skowronek 2008, 117-149, quote from 135).

Whether or not this promise of "Reagan plus" allows for realignment from within remains unanswered. But even if Skowronek does not fully take into account Rove's professed goals, he too realizes that there is something unusual in the relationship between Bush and the Republican Party. Unlike most orthodox-innovators, Bush won a second term in office. Those affiliated with the dominant regime typically experience difficulty in securing reelection, the exceptions being Madison, Monroe, Grant, and McKinley. But since Madison and Monroe were reelected prior to the introduction of competitive parties, and since Grant's reelection came with the South under occupation, McKinley is really the only one who can make this claim. More unusual, Bush garnered the support of, or at least not an open challenge from, his biggest potential party rival, John McCain. And given the tactics employed by Bush supporters during the 2000 primary in South Carolina, it was not a foregone conclusion that McCain would demonstrate that sort of loyalty (Skowronek 2008, 144-148).

Perhaps more importantly, Bush was able to maintain a level of party discipline that allowed the president to successfully pursue his policy objectives in Congress (Bass 2004; Congressional Quarterly 2005 and 2007) and without the sort of dissent and derision that is usually experienced by those who practice the politics of articulation. While his assessment of Bush as an orthodox-innovator may confirm the continuation of the patterns of presidential leadership in "political time," Skowronek also postulates the possibility that the president's ability to maintain an unchallenged position of leadership may indicate the extent to which these patterns of presidential authority have been altered by new political resources at Bush's disposal. In other words, Bush's term in office may mark a fundamental transformation of leadership as presidents come to be able to mold political parties to suit their particular needs (Skowronek 2008, x-xiii and 147-149). 
Skowronek is not convinced that this potentially "secular" transformation of the Republican Party has occurred (or that it has extended to the Democrats), but it is one possibility. Divisions within the president's own party began to appear shortly after Bush's reelection as the president was increasingly criticized for his efforts in Iraq (it is not unusual for orthodoxinnovators to engage in unnecessary military excursions at the urging of one faction within the dominate coalition only to be challenged by other members), his inability to control spending (including his acceptance of earmarks as a means for party leaders such as Hastert and Delay to entice party loyalty), and his attempts at Social Security and immigration reform (which failed despite the political capital the president thought he had accrued in being reelected). Finally, Bush's efforts to address the potential collapse of financial markets in September and early October of 2008 were meet with skepticism, outright disappointment, and two momentary revolts within his own party as conservative Republicans first walked out of bipartisan negotiations and then voted down the first attempt to pass the bill in the House.

Wilentz offers a third interpretation of the Bush presidency, arguing that devastating policy misjudgments along with the corruption of the Republican Party marks the end of the Reagan Revolution, making Bush not only a failed president, but perhaps "the worst president in history" (Wilentz 2008, para. 1-2, 25-31, 33-35; Wilentz 2006; McElvaine 2008). Wilentz believes that while Bush allowed Delay and other party leaders to go essentially unchecked, these leaders in return provided unquestioned loyalty to most of Bush's initiatives, even the most dangerous ones. Although he does not invoke Skowronek's typology in constructing his argument, the comparison of the collapse of the Reagan coalition to the disappearance of the Whigs in the 1850s, the failure of the GOP under Hoover in 1932, and fracturing of the Democrats between 1968 and Reagan's redefining victories in 1980 and 1984 , is consistent with both realignment periodization and the cycle of repudiation and reconstruction of vulnerable regimes in "political time." And the placement of Bush among some of the most maligned presidents in history (Hoover, Andrew Johnson, and Buchanan) is compatible with Skowronek's definition of the politics of disjunction. In fact, Hoover, Johnson, and Buchanan represent two disjunctive presidents and one preemptive president who suffered impeachment (Wilentz 2008, para. 3-7; Wilentz 2006, para. 8; Skowronek 1997, 39-41, and 43-45).

If the collapse of the Republican Party in elections of 2006 and 2008 signals the end of the Reagan Revolution, Skowronek's observation about Bush's incessant recitation of his commitment to conservative values as a means of distancing himself from both his father and his predecessor in office takes on a particular ironic twist. And this irony is magnified as the president was forced to face the economic crisis brought on by sub-prime 
mortgages and an under-regulated financial market in the fall of 2008. Howard Fineman's recent claim that the "bailout ushers in the era of Obama" (whether Obama actually won the presidency or not) captures this irony. Fineman was not suggesting that the election really no longer mattered, he was suggesting that the bailout may signal the end of the conservative governing commitments defined by Reagan and the return of at least some of the commitments articulated by FDR (Fineman 2008).

This analysis gained support with Obama's election and his perceived mandate to change the course of American politics. Whether this mandate measures up to the sort of fundamental shift of the political system that defines realignment is unknown, but opinion pieces posted by The Wall Street Journal, The New Republic, and The Washington Post have argued that a fundamental shift in political identification and ideological principle may have indeed occurred (Healy 2008; Judis 2008; Meyerson 2008). And the financial crisis could just be the sort of event to trigger realignment, specifically if it leads to a "downturn in the business cycle" (Judis 2008, para. 18-24; Beck 1997). But whether the crisis results in political realignment or not, Bush was put in the awkward position of having to both articulate the limits of the market as a means of organizing economic activity and proclaim the necessity of the government. And although a positive role for government is one of the defining features of "compassionate conservatism," this does not seem to be the sort of government spending and increased regulation the president had in mind.

Of course, these three accounts of Bush's presidency are not completely incompatible. Even though "third way" presidents and faithful sons are defined by their different relation to the dominant regime, the accounts posed by Milkis and Skowronek may simply reflect the similarity between politics of preemption and articulation: both present an interpretation (an altered understanding) of the received political principles in an attempt to secure electoral victory and policy success without completely rupturing and redefining the core commitments of the dominant regime. And since presidents do not begin their term with the aspiration of the sort of failed leadership associated with the politics of disjunction, the analysis offered by Wilentz that the defeat of the GOP signals the repudiation of the Reagan Revolution and realignment of the American political system may well supplant the interpretations developed by Milkis and Skowronek that focused upon Bush's first term in office.

\section{The 'Parties' Presidents Make}

"Herein lies an unexpected avenue of departure from the characteristic political effects of presidential leadership . . . it appeared that if leadership 
patterns that have been typical of the American system were to wash out, it would probably be by the development of the modern accouterments of the administrative management and by the weakening of political ties among elites as each taps the new resources available for independent political entrepreneurship. . . . [But Bush] strengthened the ties of party government and built a party organization that would operate more exclusively that ever before as a tool of presidential management. To the extent that new parties like these take hold, they will be, in effect, whatever the president needs them to be, and whatever capacity they once had to hold their leaders to account for the collective project would be correspondingly diminished" (Skowronek 2008, 148).

—Stephen Skowronek, Presidential Leadership in Political Time

Rather than answer the question of whether Bush's “compassionate conservatism" should be considered reconstructive on the terms that Rove proposed, preemptive as a style of "third way" politics, simply as an articulation of the Reagan Revolution (or perhaps a more sophisticated orthodoxy that may allow for the sort of realignment that McKinley was able to fashion in 1896), or a disjunction that marks the end of Republican political dominance, I want to suggest (if only tentatively) a different possibility-these interpretations of Bush's legacy may actually capture an historical trajectory that is consistent with a system of party government organized around presidential leadership. The idea that the Bush presidency may mark a new, and potentially dangerous, foundation for presidential power has been suggested by Skowronek, and I believe it is a promising one. By turning our attention away from an exclusive focus upon "political time," we may have a clearer picture of how parties and the presidency have developed and how this development may have altered presidential authority (Skowronek 2008, $\mathrm{x}$-xiii and 147-149).

After twelve years of divided government (1980 to 1992), the last three presidents have been elected with their party already in control of Congress (although both Clinton and Bush experienced divided government for part of their term in office). In particular, Bush attempted to take advantage of the changes in both party organization and presidential leadership that have come to define contemporary politics. According to Aldrich (1995), political parties in the 1960s began to respond to changes of how politics was practiced. The previous system of partisan politics, a system dominated by state and local party organizations, gave way to a party system that stresses national organization. The parties that emerged from this transformation took on the task of providing the resources in support of candidate-centered campaigns and establishing the institutional discipline necessary for governance once the election placed party members in office, a discipline and 
policy focus that is easier to maintain since the parties are now founded upon a more clearly defined set of ideological commitments and programmatic objectives (Aldrich 1995; Herrnson 2002; Milkis 1999; Sinclair 2002).

As Skowronek has pointed out, this may be especially true for the GOP (Skowronek 2008; 146-149), but the transformation of the Republicans into a more ideologically coherent party, and their success in electoral politics, has produced calls for the Democrats to follow suit (Gilman 2008; Davis 2008; Judis 2008). If nothing else, since the 1980s partisanship has become more evident in Congressional debates and voting patterns, and in the composition of the leadership and the rank and file in both parties (Sinclair 2002). Or put another way, although there is debate about whether or not Americans are increasingly divided on intractable partisan lines (Campbell 2008; Fiorina 2008), the parties that claim to represent them are both more ideologically defined and better organized to elect candidates and enact policies that reflect their commitments once in office.

In becoming more internally cohesive, and in organizing themselves to aide candidates in their individual campaigns, these modern parties seem to have combined some of the attributes of "responsible" party government and presidential leadership as proposed by Woodrow Wilson (Tulis 1987, 118137; Milkis 1999, 8-9 and 74-79). Specifically, parties are more inclined to perform one of the most important functions identified by Wilson: they help unify and direct public policy across a fractured system of governance by initially forming around the presidential candidates as they campaign for the people's support and maintaining the party discipline necessary to put the winning candidate's agenda into effect. And this relationship between the president and the party may be more likely given that the ideological consistency and orientation towards policy of these new parties makes programmatic agendas more appealing (even if they are essentially the work of the presidential candidates).

If Bush's presidency (and perhaps the election of Obama) reflects some new desire on the part of the American people for unified party government, and if presidents are willing to pursue this course of governance, a hybrid form of presidential leadership may be the result. Milkis's argument that Bush began his presidency as a "third way" leader distancing himself from some of the most conservative commitments of his own party may actually 'fit' with Skowronek's observation that Bush was a faithful son who appealed to the Reagan legacy as a source of political authority. Together these two interpretations frame a dual strategy that may be employed to win general elections (even if those elections are contested by two ideologically defined political parties). Although the parties have become more cohesive, the number of moderates and independents in the United States remains significant in determining the outcome of any given election. In fact, there is 
evidence that the American electorate is not as polarized as it is often portrayed, and specifically, not as polarized as the parties; self-identified moderates are not in danger of disappearing, having actually increased in numbers over the last 30 years (Fiorina 2008, 94-97). And in 2000, more Americans declared themselves as independents (40 percent) than as affiliated with either party (Beck 2003).

Even if the nation was as polarized as political observers claim, national elections have remained competitive. Despite the growth of the Republican Party since the 1960s, more Americans identified with the Democratic Party at least until the election of 2004 (and the evidence is not clear that their advantage in party identification ended then). And it remains to be seen whether or not Obama's landslide in 2008 altered this competitive landscape. An essential component of Obama's victory was the overwhelming support he received from Blacks and Hispanics, but it is not clear that these constituencies will be passed on intact to the new president's successor or the Democratic Party. Before running for president, Bush was able to win reelection as Governor in Texas with 69 percent of the total vote, 27 percent of the Black vote, and an astounding 49 percent of the Hispanic vote. Whether or not Republicans can reformulate their programmatic agenda to draw support from the Democratic coalition is unknown, but some exit polls suggest that conservative black voters mobilized by Obama's candidacy (and who presumably supported the new president) were also critical to the passage of California’s Gay Marriage Ban.

But if neither party can claim a clear majority of Americans, candidates (especially those running for the presidency for the first time) will need support from independents (or defectors from the other party) in order to win. So while Bush may have depended more on the conservative base of the Republican Party than previous candidates (Campbell 2008, 22-33), he still needed to win over some moderate voters. So even though they may be closely affiliated with the party activists especially during their run in the primaries (Polsby and Wildavsky 1996, 320-322), candidates may also construct either the sort of appeals that are associated with preemptive presidents or they may compose their particular articulation of the dominant commitments as more moderate. And while moderate and independent voters remain important to winning elections, candidates will continue to have to mobilize their core constituents. Thus, the preemptive-articulation hybrid may actually take on increased significance as the strategy for winning a general election contested between ideologically well defined parties.

For example, some commentators have attributed Gore's defeat in 2000 not only to his refusal to employ Clinton more actively in the campaign, but also to his decision to run on a platform that seemed to rekindle the populist spirit of the party rather than on the successes of the Clinton administration. 
Gore's decision is considered a tactical mistake since most political models had him winning the contest easily especially if he continued to remind the electorate of the relative peace and economic prosperity of the proceeding eight years (Milkis and Nelson 2003, 405-409; 411-414). However, Gore’s strategy may make more sense in a political world in which candidates must also satisfy the demands of a party faithful increasingly defined by their ideological commitments. Even those pundits who believe Obama's victory is a potential realignment acknowledge that his campaign seemed to promise both a moderate presidency that would appeal to those Americans tired of partisan bickering and a new liberal order that is more in line with the ideological commitments of the Democratic Party (Davis 2008; Judis 2008; Meyerson 2008).

Although these dual strategies are compatible since both preemptive and orthodox-innovators share a commitment to reform, but not reconstruct, dominant political values, they may be much more appealing for a candidate initially running for the presidency. The preemptive component of the hybrid strategy, however, will prove more difficult for presidents seeking reelection as they may be forced to fend off opposition during the primaries as Bush's father did in 1992 or they may have to worry about low turnout from the party faithful. Bush seemed to position himself more explicitly as a faithful son (or at least as the faithful party leader) in the run up to the 2004 election, in part, because Rove was convinced that the best way to win was to mobilize the base. And even if Bush was not forced to run for reelection as a faithful son, he ultimately came to the decision to govern as one. Relying heavily upon the Republican majority in the House, the president decided that it was in his best interest to work to expand that majority.

In 2000 Bush won a majority of Electoral College votes without achieving a majority of the popular vote and so it was not evident that he would choose to aggressively pursue his legislative agenda. But when he did proceed with that ambitious program, members of his administration offered an explanation that embodies the basic assumption of party government: since Bush had won the election, no matter the margin or the circumstances, he had been given the opportunity and the responsibility to govern. And in pursuing his agenda aggressively, it was not clear that Bush would rely exclusively upon his party in Congress to govern since the Republicans had suffered setbacks in both the House and Senate. Given these slim majorities, it was possible that the president would attempt to govern in a bipartisan fashion employing different coalitions of members of Congress for different legislation. In other words, Bush may have chosen to attempt to unite the nation rather than divide it (Fiorina 2008). For the most part, however, Bush chose to take advantage of increased party cohesion of the new party system in order to enact his policy agenda. 
According to Barbara Sinclair (2008), Bush did have important advantages which led him to eventually pursue party governance. First, although the GOP enjoyed the sort of ideological cohesiveness associated with the current party system, and although they had finally wrestled control of Congress away from the Democrats in 1994, they had not experienced their majority status with a Republican in the White House. This meant that the party leadership was willing to work closely with the president in order to finally be able to put their agenda into place. Second, as parties became more defined by their ideological positions, the institutional structure of the House was reorganized and strengthened giving the majority party leadership more control over its members. Bush and his administration decided to press these advantages, as Sinclair points out, because he realized the potential costs of having to compromise and the difficulties of building coalitions across party lines (Sinclair 2008, 169-181; Sinclair 2002).

Bush governed almost as a parliamentary president in the House, pushing his bills through intact and forcing the Democrats into a disadvantaged bargaining position in Conference even if the bills had been significantly modified in the Senate. And by carefully coordinating legislative activity through omnibus legislation, symbolic use of votes and vetoes, shared talking points, and calls for unquestioning patriotism after 9/11, the administration was able to construct a legislative strategy that was also an election strategy. Abandoning the initial bipartisan response to $9 / 11$, the president and the GOP leadership in Congress essentially escalated the divisions between the parties, forcing the Democrats to either accept most of Bush's foreign policy agenda without question (and some domestic policies like Homeland Security) or risk exposure to charges of being unpatriotic. Democratic Senator Max Cleland of Georgia, despite having lost both legs and an arm in the service of his country, became a victim of these tactics being accused during his campaign for reelection of being soft on issues of security.

But because of the close association between the agenda of the president and the ideological cohesion of the party, every election under Bush became a national contest that seemingly transformed the American polity. Rove, of course, hoped that the election of 2000 was the beginning of realignment. The midterm elections of 2002 and his reelection in 2004 were thought to provide Bush with mandates (since the elections were referendums on his presidency) allowing the president to successfully propose new tax cuts and pass legislation that guaranteed prescription drug coverage. And while the president was unsuccessful in pursuing Social Security and immigration reform in 2005, this may suggest the outer limits of what party discipline can accomplish. It may be that Social Security has remained as one of the "entitlements" of the previous order that Reagan's attempted 
reconstruction failed to dislodge (Skowronek 1997, 427-428). And it may be that immigration reform was simply too much at odds with some of the ideological commitments of the party.

This also meant that Republican loss of both the Senate and the House in 2006 amounted to a vote of no confidence. It was on the eve of yet another of these defining national elections that Wilentz and other historians were able to equate Bush's unprecedented low approval rating with the end the Republican Party as the dominant force in American politics. This is not to say that in the future all presidents leaving office will be ranked by historians as failures and incompetents. My point is that in a presidential led party system every transfer of power between the two parties will be thought of as essentially disrupting the political system and beginning politics anew. This may actually be typical as political observers attempt to explain the shifts in electoral politics and as new officeholders attempt to remake the political order, but in a system of party governance the meaning given to these transfers of power is always more significant. And if a president is fortunate enough to serve two terms, the resulting election to replace him or her may be, as was the case in both 2000 and 2008, an almost surreal campaign in which both Democratic and Republican candidates run as agents of change opposing the president.

\section{Conclusion}

If presidents continue to be elected with their political party having control of Congress, and if this trajectory of presidential led party government continues (i.e., a politics of preemption-articulation that define an election strategy and that promises the possibility of the reconstruction of the political order once in office, to a politics of articulation especially in terms of governing, and finally to a politics of disjunction as a president's term in office comes to an end), then I think that three important concerns about this new party system will require increased study.

First, although presidents would get certain advantages from enhanced party discipline in Congress, the ideological cohesion of the party may put important limits on presidents' ability to formulate and enact innovative policy. For Bush, control by the GOP did not guarantee the passage (or even much discussion) of Social Security or immigration reform despite the importance of those issues to the nation and to his own plan to attract new voters for the Republican Party. In both cases, despite a programmatic agenda and a more unified structure of party governance, the president and his party failed to address and solve difficult political problems (Polsby and Wildavsky 1996, 320-326; King 1997). Perhaps of even more concern, the closer bonds between the president and Congress promised by party 
government may continue to blur, or even do away with entirely, the boundaries that separate governing from the electoral strategies employed while running for office, making it even more difficult to address complex problems.

Second, the increased ideological cohesion of the party may push presidents away from more inclusive political strategies. Although Bush was not successful in achieving his entire legislative agenda, he may have been even less successful if he had attempted to duplicate the bipartisan strategy he favored in Texas, opening himself up to attacks from the right (but with the added disadvantage that the GOP controlled Congress). Or if he chose to practice the politics of preemption, Bush may have continued to be challenged by the Democrats while receiving unsteady support from his own party. And Obama may face just this choice. If he attempts to utilize the advantages of working with a disciplined party leadership, he may be forced to abandon his promises of bipartisan cooperation, and if he pursues that cooperation, he may not only forfeit those institutional advantages accrued by having a Democratic majority in Congress, he may also invite challenges (and challengers) from his own party that would make reelection more difficult.

Finally, this party discipline may allow presidents to increase their power both in terms of administrative authority and by squelching opposition within their own party. The origin of political parties in the United States was a response not only to concerns about coordinating political actively like those articulated by Wilson, but also a means of controlling the political ambitions of the executive officer, supplementing constitutionally designed checks (Milkis 1999, 18-21). Claiming the need to secure the United States after the terrorist attacks on 9/11, Bush engendered constitutional controversies over the power exercised by the his office with little or no oversight from a well-disciplined Republican Congress (Fisher 2006; Kassop 2006). Finally, while political parties can limit presidential authority as they build consensus among the diverse commitments and interests that are joined together in coalitions seeking to win public office, the experience of party governance under Bush suggests that rather than work to build consensus among party leaders, the president relied upon party discipline to not only protect him from institutional oversight, but to control dissent with the party as well.

\section{REFERENCES}

Aldrich, John H. 1995. Why Parties?: The Origin and Transformation of Political Parties in America. Chicago, IL: University of Chicago Press. 
Bass, Harold F. 2004. George W. Bush, Presidential Party Leadership Extraordinaire? The Forum 2(4).

Beck, Paul A. 1997. Party Politics in America, 8th ed. New York: Longman.

Beck, Paul A. 2003. A Tale of Two Electorates: The Changing American Party Coalitions, 1952-2000. In The State of the Parties: The Changing Role of Contemporary American Parties, eds. John C. Green and Rick Farmer. Lanham, MD: Rowman and Littlefield Publishers, Inc.

Campbell, James. 2008. Presidential Politics in a Polarized Nation. In The George W. Bush Legacy, eds. Colin Campbell, Bert Rockman, and Andrew Rudalevige. Washington, DC: CQ Press.

Davis, Lanny J. 2008. The Obama Realignment. The Wall Street Journal, Opinion Journal, WSJ.com. (November 6) http://www.careerjournal.com/article/SB12259 3028681903153.html?mod=most viewed opinion24\#articleTabs\%3Darticle (Accessed online 11/08/2008).

Fineman, Howard. 2008. Bailout Ushers in the Era of Obama. MSNBC (September 29) http://www.msnbc.msn.com/id/26933982/ (Accessed online 11/10/2008).

Fiorina, Morris P. 2008. A Divider, Not a Uniter-Did it Have to Be? In The George W. Bush Legacy, eds. Colin Campbell, Bert Rockman, and Andrew Rudalevige. Washington, DC: CQ Press.

Fisher, Louis. 2006. From Presidential Wars to American Hegemony: The Constitution After 9/11. In The Presidency and the Challenge of Democracy, eds. Michael A. Genovese and Lori Cox Han. New York: Palgrave Macmillan.

Gilman, Nils. 2004. What the Rise of the Republicans as America's First Ideological Party Means for the Democrats. In The Forum (2)1.

Green, Joshua. 2007. The Rove Presidency. The Atlantic, webpage (September 2007) http://www.theatlantic.com/doc/200709/karl-rove (Accessed online 10/25/2008).

Herrnson, Paul S. 2002. National Party Organizations at the Dawn of the Twenty-First Century. In The Parties Respond: Changes in American Parties and Campaigns, ed. L. Sandy Maisel. Boulder, CO: Westview Press.

Judis, John. 2008. America the Liberal. The New Republic, webpage (November 5) http://www.tnr.com/politics/story.html?id=c261828d-7387-4af8-9ee7-8b2922ea6df0 (Accessed online 11/08/2008).

Kassop, Nancy. 2006. The Constitutional Checks and Balances that Neither Check Nor Balance. In The Presidency and the Challenge of Democracy, eds. Michael A. Genovese and Lori Cox Han. New York: Palgrave Macmillan.

King, Anthony. 1997. The Vulnerable American Politician. In British Journal of Political Science 27(1).

Ladd, Everett C. 1990. Like Waiting for Godot: The Uselessness of Realignment for Understanding Change in Contemporary American Politics. Polity 22(2).

Lemann, Nicholas. 2003. The Controller. The New Yorker, webpage (May 12, 2003) http://www.newyorker.com/archive/2003/05/12/030512fa fact lemann? (Accessed online 11/04/2008).

McElvaine, Robert S. 2008. HNN Poll: 61\% of Historians Rate the Bush Presidency Worst. History News Network, http://hnn.us/articles/48916.html\%22 (Accessed online 11/03/2008).

Meyerson, Harold. 2008. A Real Realignment. Washingtonpost.com (November 7) http://www.washingtonpost.com/wpdyn/content/article/2008/11/06/AR2008110602 571.html?hpid=opinionsbox1 (Accessed online 11/08/2008).

Milkis, Sidney M. 1999. Political Parties and Constitutional Democracy: Remaking American Democracy. Baltimore, MD: Johns Hopkins University Press. 
Milkis, Sidney M. and Michael Nelson. 2003. The American Presidency: Origins and Development 1776-2002. Washington, DC: CQ Press.

Neustadt, Richard. 1960 and 1980. Presidential Power: The Politics of Leadership from FDR to Carter. New York: Macmillan Publishing Company.

Panagopoulos, Costas, and Daniel Bergan. 2006. Contributions and Contributors in the 2004 Presidential Election Cycle. Presidential Studies Quarterly 36(2).

Polsby, Nelson, and Aaron Wildavsky. 1996 (original copyright 1964). Presidential Elections: Strategies and Structures of American Politics. Chatham, NJ: Chatham House Publishers, Inc.

Rove, Karl. 2002. What Makes a Great President? Lecture delivered at the University of Utah's Rocco C. Siciliano Forum, November 13, 2002. History News Network. http://hnn.us/articles/1529.html (Accessed online 11/03/2008).

Sinclair, Barbara. 2008. Living (and Dying) by the Sword. In The George W. Bush Legacy, eds. Colin Campbell, Bert Rockman, and Andrew Rudalevige. Washington, DC: CQ Press.

Sinclair, Barbara. 2002. The Dream Fulfilled? Party Development in Congress, 19502000. In Responsible Partisanship? The Evolution of American Parties Since 1950, eds. John C. Green and Paul S. Herrnson. Lawrence,: University Press of Kansas.

Skowronek, Stephen. 1993 and 1997. The Politics Presidents Make: Leadership from John Adams to Bill Clinton. Cambridge, MA and London: The Belknap Press of Harvard University Press.

Skowronek, Stephen. 2008. Presidential Leadership in Political Time: Reprise and Reappraisal. Lawrence: University Press of Kansas.

Sundquist, James L. 1988-1989. Needed: A Political Theory for the New Era of Coalition Government in the United States. Political Science Quarterly 103(4).

Tulis, Jeffrey K. 1987. The Rhetorical Presidency. Princeton, NJ: Princeton University Press.

Wilentz, Sean. 2006. The Worst President in History? The Rolling Stone, webpage (April 21) http://www.rollingstone.com/news/profile/story/9961300/the worst president in_history (Accessed online 10/06/2008).

Wilentz, Sean. 2008. How Bush Destroyed the Republican Party. The Rolling Stone, webpage (September 4) http://www.rollingstone.com/news/coverstory/22665562 (Accessed online 10/06/2008). 